
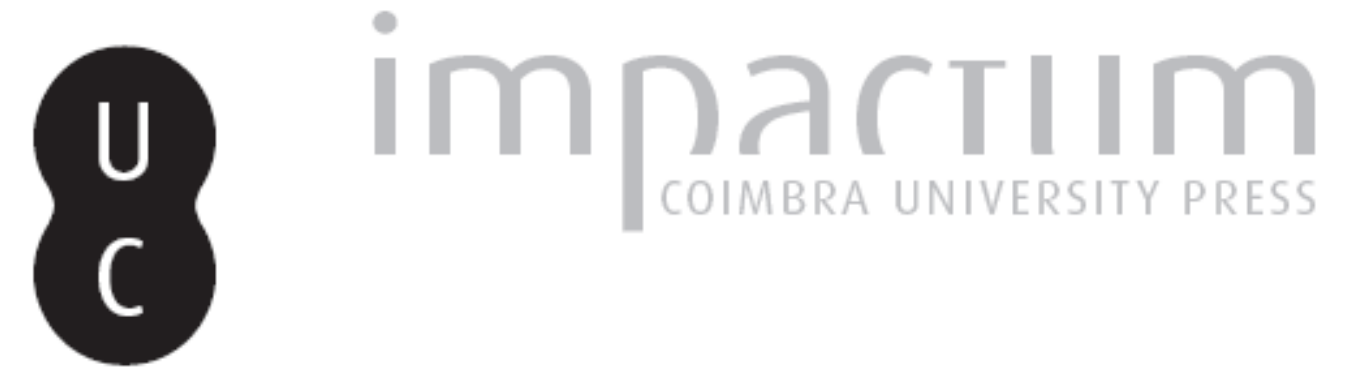

Uma outra visão do direito: as contribuições fornecidas pelas ciências sociais

Autor(es): Baptista, Bárbara Gomes Lupetti

Publicado por: Universidade Católica de Petrópolis

URL persistente:

URI:http://hdl.handle.net/10316.2/33905

DOI:

DOI:http://dx.doi.org/10.14195/2175-0947_1-1_7

Accessed : $\quad$ 26-Apr-2023 13:43:15

A navegação consulta e descarregamento dos títulos inseridos nas Bibliotecas Digitais UC Digitalis, UC Pombalina e UC Impactum, pressupõem a aceitação plena e sem reservas dos Termos e Condições de Uso destas Bibliotecas Digitais, disponíveis em https://digitalis.uc.pt/pt-pt/termos.

Conforme exposto nos referidos Termos e Condições de Uso, o descarregamento de títulos de acesso restrito requer uma licença válida de autorização devendo o utilizador aceder ao(s) documento(s) a partir de um endereço de IP da instituição detentora da supramencionada licença.

Ao utilizador é apenas permitido o descarregamento para uso pessoal, pelo que o emprego do(s) título(s) descarregado(s) para outro fim, designadamente comercial, carece de autorização do respetivo autor ou editor da obra.

Na medida em que todas as obras da UC Digitalis se encontram protegidas pelo Código do Direito de Autor e Direitos Conexos e demais legislação aplicável, toda a cópia, parcial ou total, deste documento, nos casos em que é legalmente admitida, deverá conter ou fazer-se acompanhar por este aviso.

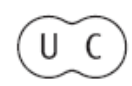



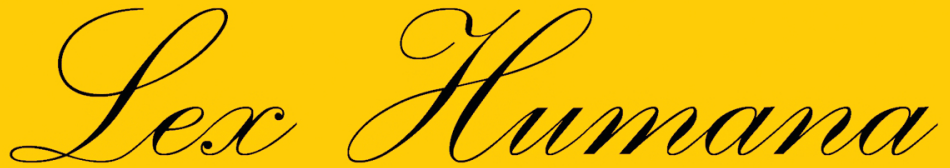

Revista do Programa de Pós-Graduação em Direito da UCP

ISSN(e) 2175-0947

Universidade Católica de Petrópolis Rua Benjamin Constant, 213 - Petrópolis - Centro CEP 25610-130

Tel: (24) 2244-4000 E-mail: lexhumana@ucp.br 


\section{UMA OUTRA VISÃO DO DIREITO: \\ AS CONTRIBUIÇÕES FORNECIDAS PELAS CIÊNCIAS SOCIAIS ${ }^{1}$}

Bárbara Gomes Lupetti Baptista

1. Considerações iniciais

Sejam quais forem as outras características que a antropologia e a jurisprudência possam ter em comum - como por exemplo uma linguagem erudita meio incompreensível e uma certa aura de fantasia - ambos se entregam à tarefa artesanal de descobrir princípios gerais em fatos paroquiais [...] No entanto, essa sensibilidade pelo caso individual pode tanto dividir como unir [...] A interação de duas profissões tão voltadas para a prática, tão profundamente limitadas a universos específicos e tão fortemente dependentes de técnicas especiais, teve como resultado mais ambivalência e hesitação que acomodação e síntese [...]. (GEERTZ, 1998, p. 249)

A proposta principal deste trabalho é tentar expor as relevantes contribuições que as ciências sociais podem fornecer à compreensão do Direito e ao desenvolvimento da pesquisa jurídica. Para fazê-lo, parto de uma experiência pessoal, vivenciada durante a elaboração da minha

$1 \quad$ Kant de Lima escreveu um artigo fundamental, discorrendo sobre a contribuição da Antropologia para a pesquisa jurídica no Brasil. Ver: KANT DE LIMA, Roberto. Por uma Antropologia do Direito no Brasil. In: FALCÃO, Joaquim de Arruda. Pesquisa Cientifica e Direito. Recife: Massangana, 1983. p. 89-116. As características comuns existentes entre o Direito e a Antropologia também são retratadas de forma singular por GEERTZ em "O saber local: fatos e leis em uma perspectiva comparativa" (1998). 
dissertação de mestrado ${ }^{2}$, cujo resultado me permitiu olhar o Direito sob o viés antropológico e, por isso, enxergar aspectos e mecanismos do nosso sistema judiciário que eu não teria percebido se não tivesse me valido da pesquisa de campo ${ }^{3}$ que realizei e do diálogo produtivo que me permiti fazer com as ciências sociais.

Utilizar ferramentas de outras áreas do conhecimento - no meu caso, da Antropologia - parece-me fundamental para repensar a estrutura do Direito e a forma como ele se manifesta.

O Direito precisa analisar e (re) pensar as suas práticas e, para tanto, precisa se abrir às contribuições de outras áreas do conhecimento, sob pena de, por se fechar demais, não conseguir dar conta dos seus próprios institutos e, por conseguinte, dos seus problemas, dos seus paradoxos e das suas crises. Bourdieu, Chamboredon e Passeron nos remetem a essa temática, destacando-se o seguinte trecho de sua obra:

2 O título da dissertação, defendida, em maio de 2007, no âmbito do Programa de Pós-graduação em Direito da Universidade Gama Filho, sob a orientação do Professor Roberto Kant de Lima, é: "O Princípio da Oralidade às avessas: um estudo empírico sobre a construção da verdade no processo civil brasileiro.".

$3 \quad$ Fazer trabalho de campo é conviver intensamente com o objeto de estudo; é vivenciá-lo (MALINOWSKI, 1984).Utilizei-me da etnografia e da observação participante como métodos para a elaboração da pesquisa que resultou na minha dissertação de mestrado. Ou seja, fiz pesquisa de campo no Tribunal de Justiça do Estado do Rio de Janeiro, entrevistando Juízes, advogados, partes e serventuários. O meu ponto de partida foi o discurso desses operadores, diretamente envolvidos nas práticas judiciárias, e que funcionaram como meus interlocutores. Igualmente, na qualidade de advogada, de alguma forma eu estava inserida no campo pesquisado, de forma que a minha presença cotidiana e minha atuação freqüente no Tribunal, contribuíram para a minha familiarização com o tema investigado, de modo que eu não fui apenas uma espectadora na pesquisa de campo, mas, efetivamente, parte atuante nesse contexto. Eu não era, outrossim, uma pesquisadora alheia ao campo, eu era uma pesquisadora, em alguns momentos, e uma advogada atuante, em outros. Nas palavras de Kant de Lima, "o ponto central do método etnográfico é a descrição e a interpretação dos fenômenos observados com a indispensável explicitação tanto das categorias 'nativas' como aquelas do saber antropológico utilizado pelo pesquisador [...] A convivência e participação na vida dos grupos costuma-se denominar observação participante [...]". (Kant de Lima, 1983). Para visualizar como fazer etnografia, utilizando-se da observação participante, ver: FOOTE-WHYTE, 1975, p. 77-86. 
A obediência incondicional a um organon de regras lógicas tende a produzir um efeito de 'fechamento prematuro' fazendo desaparecer, para falar como Freud, 'a elasticidade nas definições' ou, como diz Carl Hempel, 'a disponibilidade semântica dos conceitos' que, pelo menos em certas fases da história de uma ciência ou do desenrolar de uma pesquisa, constituem uma das condições da invenção [...] Toda operação, por mais rotineira e rotinizada que seja, deve ser repensada, tanto em si mesma quanto em função do caso particular. (BOURDIEU, CHAMBOREDON, PASSERON, 2004, pp. 14 e 18).

O meu esforço em tentar dialogar com a Antropologia adveio especialmente do contacto que tive a oportunidade de desfrutar com o Professor Roberto Kant de Lima, advogado e antropólogo, e com a Professora Maria Stella de Amorim, socióloga, ambos Professores do Programa de Pósgraduação da Universidade Gama Filho, onde cursei o mestrado em Direito. Mas não só. Penso que algo antecedeu (e justificou) esse encontro.

Hoje, revendo a minha trajetória pessoal e profissional, entendo que o que me fez buscar uma nova (diferente) forma de compreender o Direito foi, por um lado, a minha absoluta incapacidade de conformação diante daquilo que, sensitivamente, me parece "fora de lugar"; e, por outro lado, a necessidade que eu tinha de encontrar respostas, que o Direito não me fornecia, seja nas Leis, nos livros ou nos manuais, sobre a sua própria estrutura e sobre os seus, nitidamente falhos, mecanismos de funcionamento.

Como estudante do Direito e, ao mesmo tempo, como advogada ou seja, operadora efetiva no campo ${ }^{4}$ - eu estranhava muito a discrepância abissal verificada entre o discurso dogmático e a realidade empírica ${ }^{5}$."Ler"

$4 \quad$ Utilizo a expressão "campo do direito", aqui e doravante, com o mesmo sentido de cultura ("cultura jurídica"), o qual, nos dizeres de Bourdieu, seria "o que permite a todos os detentores do mesmo código associar o mesmo sentido às mesmas palavras, aos mesmos comportamentos e às mesmas obras e, de maneira recíproca, de exprimir a mesma intenção significante por intermédio das mesmas palavras, dos mesmos comportamentos e das mesmas obras [...]". (BOURDIEU, 1987). 
os livros de Direito era, ou melhor, é, completamente diferente de "ver" a sua materialização nas práticas judiciárias. Ocorre que, para mim, hoje, com a estrutura de pensamento que eu construí a partir do contacto com as ciências sociais, não me parece estranho que assim seja. Eu entendi que o Direito visa ao "dever-ser" e, nesse sentido, se concebe como um ideal que não tem ou não precisa ter qualquer compromisso com a realidade. Mas, antes, quando eu me iniciei no campo, era incompreensível pensar o Direito de forma absolutamente desatrelada do cotidiano forense.

A minha vivência como advogada e a falta de respostas para práticas diárias realizadas a todo o instante nos Tribunais não me parecia plausível e acho que foi essa sensibilidade e essa percepção que me fizeram ir em busca dos obscuros desse campo e tentar perceber qual era o mecanismo que permitia que o Direito assim se estruturasse. Quer dizer, eu queria compreender o porquê de as pessoas não estranharem o fato de os livros apontarem algo completamente diferente daquilo que acontecia nos muros circunscritos dos Tribunais.

A pesquisa de campo foi o que me permitiu entender um pouco melhor isso e outros fatores mais, que pretendo compartilhar nesse trabalho.

Aliás, impõe destacar desde logo, o caráter altamente pessoal deste trabalho, que é muito mais fruto da minha experiência acadêmica e profissional, do que da leitura ou da compreensão "teórica" do Direito e de seus institutos.

Ver o Direito sob outra perspectiva que não a sua própria, foi - e tem sido - uma experiência muito rica para mim e tem facilitado bastante a

o antropológico, e percebeu as disparidades entre a dogmática e as práticas judiciárias. Chama a atenção o seguinte trecho do seu livro "Em tempo de conciliação" (2003, p. 27-28): "[...] o estudo antropológico do Direito parte da sua compreensão como instância ordenadora e controladora, passa pela interpretação das instituições jurídicas e judiciais e das teorias que o impregnam, atingindo o sistema jurídico como um todo, no momento e nos espaços sociais particularizados em que aquelas instituições e teorias se desenvolvem. Isto implica, portanto, visualizar a ordem legal criada no ordenamento jurídico e a ordem vigente no cotidiano da sociedade, seus cruzamentos, suas superposições, mas também os afastamentos e as disparidades existentes entre elas [...] a socialização dentro desse campo [do direito], produz um saber que ultrapassa a fundamentação de leis, sentenças, pareceres etc., dos poderes executivo, legislativo e judiciário e as atividades técnicas e extrajurídicas. O estudo interpretativo desse saber conduziu à sua percepção como formalmente distante da realidade social [...].”. 
compreensão sobre a minha atividade e sobre a sistemática do meu campo de atuação.

Por derradeiro, ressalto que o método adotado na minha pesquisa busca revelar não apenas os obscuros, mas também os "óbvios" do campo, eis que estes, nem sempre são descritos ou explicitados nos manuais e livros jurídicos, sendo, ocasionalmente, conhecidos por um número limitado de pessoas, em geral, aquelas que atuam rotineiramente nos Tribunais. Assim, a partir dessa proposta descritiva, vez ou outra, o texto pode parecer, para alguns, traçar meras obviedades do Judiciário, no entanto, trata-se de um mecanismo proposital. A sociedade não está socializada com o Direito, não conhece as suas regras e, por conseguinte, não legitima as suas práticas. Entendo que uma forma viável de minimizar essa distância que separa o que deveria estar próximo, por ser complementar - os Tribunais e a sociedade - é tornar conhecidos e explícitos os rituais judiciários.

O Direito, freqüentemente, encoberta os óbvios, pelo fenômeno da naturalização, sendo certo que explicitá-los, a meu ver, nesse contexto, parece bastante relevante.

Kant de Lima, neste diapasão, ressalta que o papel da Antropologia é justamente este: utilizando-se do conhecimento das diferenças entre as sociedades humanas, "estranhar" sua própria sociedade, descobrindo nela aspectos inusitados e ocultos por uma familiaridade embotadora da imaginação sociológica (KANT DE LIMA, 1983, p. 90). Creio que foi, exatamente, esta a influência da Antropologia na minha pesquisa e na minha atuação profissional.

O viés antropológico permitiu-me enxergar além dos muros da dogmática, facilitando uma visão macro, ou interdisciplinar, do nosso sistema judiciário. A tradição do ensino jurídico, dogmático, fecha as perspectivas do conhecimento. O Direito é por demais hermético, daí a dificuldade de reconhecer e legitimar outros campos do conhecimento, mesmo sendo cediço o fato de se tratar, o Direito, de uma disciplina que não pode se compreender a partir de sua própria estrutura, lógica e sistemática interna.

A idéia de compartilhar alguns dados e o desenrolar da minha pesquisa através deste artigo visa, tão-somente, facilitar a compreensão de certos aspectos do Direito que me foram explicitados a partir do diálogo com a Antropologia e que eu reputo interessantes para repensar o campo jurídico.

2. A naturalização: um fenômeno próprio do campo jurídico 
A mim sempre pareceu "estranho" o convívio harmônico e natural de dois tipos absolutamente distintos de formação predominantes no campo do Direito: a educação formal, estabelecida na graduação, nas universidades; e a educação informal, presente no cotidiano forense, nos Tribunais.

"Estranhar" o objeto de investigação, "relativizar" o campo estudado, "desnaturalizar" as práticas judiciárias e o discurso oficial do Direito seriam, para um antropólogo, questões básicas e cruciais para o sucesso da pesquisa. Entretanto, para um advogado ou qualquer outro membro de formação jurídica, socializado nesta área, tais requisitos constituem verdadeiros empecilhos à pesquisa e foram, no meu caso, a maior dificuldade enfrentada.

Primeiro, porque não compreendemos exatamente o que essas categorias - estranhar, relativizar e desnaturalizar - significam; e, segundo, porque a formação jurídica está fulcrada em "certezas" e "verdades irrefutáveis", ao contrário das ciências sociais, onde nada é definitivo ou permanente. Kant de Lima (1983, p. 98), destaca esse fato:

A contribuição que se pode esperar da Antropologia para a pesquisa jurídica no Brasil será evidentemente vinculada à sua tradição de pesquisa. Desde logo há a advertir que o estranhamento do familiaré um processo doloroso e esquizofrênico a que certamente não estão habituadas as pessoas que se movem no terreno das certezas e dos valores absolutos. A própria tradição do saber jurídico no Brasil, dogmático, normativo, formal, codificado e apoiado numa concepção profundamente hierarquizada e elitista da sociedade, refletida numa hierarquia rígida de valores autodemonstráveis, aponta para o caráter extremamente etnocêntrico de sua produção, distribuição, repartição e consumo. (grifou-se)

Aos poucos, fui entendendo que a essência do meu estudo deveria estar fundamentada na necessidade de distanciamento do meu objeto. Para compreendê-lo, eu deveria valorizar os dados da realidade, desprendendo-me dos marcos teóricos que fundamentaram a minha 
formação em Direito. Logicamente, foi - e ainda é - extremamente difícil para mim, desconstruir as verdades reveladas durante a minha formação e as "certezas" do Direito, fincadas e internalizadas em mim de uma forma bastante marcante, mas ter isso em mente já foi um caminho importante, que me levou ao reconhecimento da importância de questionar e entender o porquê de as coisas serem ou se expressarem de determinado modo ${ }^{6-7}$.

$\mathrm{O}$ questionamento e a relativização são categorias que aprendi na Antropologia e que, de alguma forma, representam a valoração do discurso do interlocutor, ou seja, daquele que está nos ajudando a enxergar o campo a partir da perspectiva de quem está inserido nele. No Direito, a importância disso se multiplica, uma vez que a única forma oficialmente difundida de compreender o sistema é lendo livros e manuais de pessoas "autorizadas" a escrever sobre determinados assuntos, independentemente de a realidade das práticas judiciárias nos mostrar, todos os dias, que o que está nos manuais não existe nos Tribunais.

$\mathrm{O}$ trecho a seguir me ajudou a entender um pouco esse mecanismo de relativização:

A antropologia, lá ou cá, na floresta ou na cidade, na aldeia ou na metrópole, não dispensa o caráter relativizador que a presença do 'outro' possibilita. É esse jogo de espelhos, essa imagem de si refletida no outro que orienta e conduz o olhar em busca de significados ali onde, à primeira vista, a visão desatenta ou preconceituosa só enxerga exotismo, quando não o perigo, a anormalidade.. ${ }^{8}$

Nesse contexto, chama a atenção e influi sobremaneira na formação dos operadores do Direito, o fato de essa disciplina se reconhecer como

$6 \quad$ Bourdieu (1987) trata desse assunto quando menciona no capítulo que trabalha os sistemas de ensino e sistemas de pensamento, que "[...] quanto mais tais esquemas [de pensamento] encontram-se interiorizados e dominados, tanto mais escapam quase que totalmente às tomadas de consciência [...]".

7 Sobre a influência da formação escolar - no caso, a formação jurídica - na construção do pensamento e da cultura de um determinado grupo, ver BOURDIEU (1987) e BERMAN (1996).

8 Magnani, Jose Guilherme Cantor. Quando o campo é a cidade: fazendo antropologia na metrópole. Disponível em: http://www.n-a-u.org/ QUANDOOCAMPOCAPI.pdf 
um conjunto normativo ideal.

Vincular o Direito ao campo do “dever-ser” é um equívoco que o estudo das práticas judiciárias, segundo o método antropológico, ajuda a explicitar. O mundo do "dever-ser” deve estar atrelado a uma preocupação filosófica, não jurídica. O Direito é um campo prático, empírico, que existe para administrar os conflitos entre as pessoas, seres de carne e osso, que precisam ter os seus problemas cotidianos administrados pelos Tribunais.

Pensar em como as coisas deveriam ser não pode ser uma problemática jurídica. O "mundo do Direito" é o mundo real. Garapon (1997, p. 180) destaca que

[...] um direito demasiado ideal é muitas vezes inaplicável", de modo tal que "o distanciamento entre o direito dos livros e o direito vivido tornouse perigoso", tendo em vista que, para ele, a distorção entre o que a lei determina e o que a prática realiza causa uma "anomia", decorrente não da ausência do Direito, mas do seu "caráter demasiado abstrato.

Oportuno destacar que, também nesse contexto, a Antropologia dá a sua contribuição, pois a pesquisa de campo é, nada mais nada menos, do que a possibilidade de vivenciar a materialização empírica do Direito, deixando de lado o que os códigos prevêem e o que as Leis determinam para explicitar o que, de fato, as pessoas vinculadas ao campo dizem que sentem e vêem acontecer todos os dias.

O mundo jurídico é estabelecido e legitimado, internamente, como uma esfera à parte das relações sociais, ocorre que, em realidade, o Direito não pode ser estudado de forma dissociada do seu campo social de atuação porque ele é parte do controle social. Em sendo assim, o Direito não pode ser visto como um saber "monolítico" (KANT DE LIMA, 1983).

O mundo jurídico, portanto, não deveria se constituir de um saber especializado, uma vez que a sua lógica e o seu ordenamento se difundem e atingem todas as esferas e camadas sociais. Todavia, é assim que o campo funciona e isto faz com que a produção desse saber específico implique em um tremendo distanciamento formal da realidade, que não se constitui de configurações normativas ideais, como o Direito prevê.

Assim, a realidade acaba, nesse sistema, tendo que se adaptar 
ao Direito, cuja função é - em vez de administrar conflitos - regular o comportamento social (KANT DE LIMA, 1983).

Estudar as práticas judiciárias me permitiu ver, justamente, além da concepção limitada dos códigos, leis e manuais. Eu pude observar, subsidiada pela Antropologia, as diversas representações sociais de um mesmo instituto jurídico. No caso do meu objeto de pesquisa - Princípio da Oralidade - indo a "campo" pude perceber que a dogmática lhe empresta definição única, abstrata e geral, ao passo que a empiria demonstra a existência de significados distintos para a sua materialização ${ }^{9}$.

Só a empiria nos dá um consenso sobre como as coisas, de fato, se dão no mundo prático. E esse consenso advém dos interlocutores, ou seja, das pessoas que vivenciam as práticas sobre a qual se está estudando. No Direito, a dogmática faz parecer que o objeto de estudo não é real; parece que o saber que você busca está em outro lugar; superior; ideal e inacessível; o que nos faz pensar que o próprio Direito se coloca nesse patamar de certa forma impalpável; exclusivo; não pragmático.

3. O contraditório atuando internamente: a construção do saber jurídico

O Direito se reproduz através de "doutrinas", que constituem o pensamento de pessoas autorizadas a trabalhar academicamente determinados assuntos. O saber jurídico não é científico, é interpretativo; é dogmático.

Berman (1996; p. 18), ao estudar a formação da tradição jurídica no Ocidente, aclara diversos pontos sobre a questão do Direito como sendo um saber "dogmático", definindo-o como um campo no qual não se incluem somente as instituições legais, as ordens legais, as decisões

9 É muito curioso o que ocorre quando comparamos o discurso dogmático com o empírico porque na dogmática a oralidade tem uma conotação imensamente positiva, ao passo que no discurso dos operadores, que lidam com a oralidade em seu cotidiano, ela é opostamente vista com uma conotação negativa. É tida como algo que atrapalha o bom andamento do processo e que não tem destinação, de fato, útil. Ademais, as distintas representações que a oralidade recebe, de acordo com o tempo e o espaço em que se materializa, quer dizer, na $1^{\mathrm{a}}$ instância ou na $2^{\mathrm{a}}$ instância, em uma audiência ou no gabinete de um magistrado, não são consideradas nos livros jurídicos, mas aparece de forma muito clara na pesquisa empírica. 
legais; mas também tudo aquilo que os especialistas em leis dizem acerca dessas instituições, ordens e decisões legais, tratando-se, pois, de um "meta direito".

No Direito, o conhecimento advém da interpretação das leis e as pessoas autorizadas a interpretar as leis são os próprios juristas.

A doutrina, principal formadora da construção do "saber jurídico", é uma criação advinda ou dos Tribunais - através da jurisprudência - ou dos renomados estudiosos do Direito - os Juristas - que estabelecem de que forma as normas devem ser interpretadas.

O reconhecimento das pessoas autorizadas a escrever sobre temas específicos advém especialmente dos cargos importantes que ocupam no Judiciário. As versões consagradas são "a matéria-prima sobre a qual se edifica" a formação jurídica, que se limita a avançar a partir delas, sem, no entanto, questioná-las (KANT DE LIMA, 1997).

Vale dizer que, mais especificamente do que "doutrina", o que existe no Direito são correntes doutrinárias. Ou seja, sobre quase todo tema jurídico existem grupos, compostos de pessoas renomadas no campo, que interpretam as leis de uma forma peculiar e distinta e que se contradizem mutuamente. Estes grupos são formados por juristas reconhecidos que escrevem sobre o mesmo assunto e, necessariamente, o fazem de forma contraditória; e, também, por ministros e magistrados que, ao proferirem as suas decisões nos processos também criam "doutrina", tanto que, comumente, revistas jurídicas especializadas publicam, na íntegra, sentenças ou acórdãos proferidos em processos judiciais.

As mencionadas correntes doutrinárias formam o conhecimento jurídico, isto é, constituem o "saber jurídico".

Nesse contexto, vê-se, também, que os juristas têm uma postura, de certa forma, comprometida com o tema; entretanto, os advogados por representarem interesses alheios, de seus clientes - podem um dia se aliar a uma corrente doutrinária e noutro dia, a outra, sem que isso lhes cause qualquer problema ético. Eles não precisam se posicionar a favor ou contra o tema, pois o seu papel não é de jurista; o seu papel é usar a corrente doutrinária de forma aleatória e circunstancial, ou seja, de acordo com o interesse que convier ao seu cliente num determinado momento.

Significa dizer que sempre há a possibilidade de existirem, ao menos, duas formas distintas e contraditórias de se interpretar um dispositivo legal e, é justamente isso, que faz com que, em muitas ocasiões, o Direito seja uma loteria. Se você conseguir que a sua ação 
seja distribuída para um juiz que interprete a lei de forma a atender aos seus interesses, a sorte está com você; todavia, se por acaso a sua ação for distribuída para um juiz que interprete a lei de forma a não atender aos seus interesses, o seu caso estará perdido. E tudo isso é legítimo porque é assim mesmo que o Direito funciona. A norma é abstrata e exige interpretação subjetiva e particular.

Por organizar-se através de categorias universalizantes, o Direito possibilita uma luta interna do campo para ver qual das possíveis interpretações das normas terá a melhor aceitação. A literalidade da lei não é vista como o instrumento propiciador do acesso universal das pessoas ao Direito - característica das sociedades democráticas - ao revés, é vista como simplória. (MENDES, 2003).

O campo do Direito é, logo, um campo de luta, de disputa de opiniões, onde uns ganham e outros perdem. A consagração no interior do campo do conhecimento exige uma concorrência pela legitimidade que, por sua vez, destaca os que alcançam o reconhecimento intelectual, dos demais. Distingue os "donos do saber", dos comuns. (BOURDIEU, 1987).

Bourdieu (1987) nos convoca à reflexão quando deixa no ar a assertiva: "O projeto intelectual de cada um dos contestantes tem outro conteúdo que não seja a oposição ao projeto do outro?".

Transpondo isso ao Direito, verificamos que, de fato, a preocupação dos "doutrinadores" em legitimar o seu saber é maior do que o compromisso com o conteúdo daquilo que sustentam. Muitas vezes, a competição pela consagração se resume ao contraditório ${ }^{10}$ de teses por si só, em vez de representar um efetivo comprometimento com a produção intelectual.

Os "juristas" (categoria genérica que inclui tanto os magistrados - que criam a doutrina através de suas decisões - quanto os doutrinadores que, embora consagrados, não exercem necessariamente um cargo público na estrutura hierárquica dos tribunais) disputam a produção do "saber jurídico" de forma tal que - a busca desse mencionado status de criador de um conhecimento exclusivo e único - leva à mútua desqualificação. Ou seja, ganhar a disputa interna do campo pela criação do "saber jurídico" supõe, necessariamente, desqualificar a tese oposta; e esse inesgotável 10 Este sistema de duelo (contraditório) se reproduz no processo e dificulta sobremodo o diálogo das partes e o seu acesso ao Tribunal, personalizado no magistrado. 
duelo de opiniões resulta em contradições e anulações recíprocas.

Para exemplificar, considero oportuno transcrever trecho de um voto vencido, proferido em 2003 por um Ministro do STJ ${ }^{11}$, nos autos de um processo, no qual fica clara essa disputa interna do campo, ao qual me referi, bem como essa necessidade de afirmar um "saber" específico; em geral, vinculado a um cargo de poder.

Sr. Presidente, li, com extremo agrado, o belíssimo texto em que o Sr. Ministro Francisco Peçanha Martins expõe as suas razões, mas tenho velha convicção de que o art. 557 veio em boa hora, data venia de S. Exa. Não me importa o que pensam os doutrinadores. Enquanto for Ministro do Superior Tribunal de Justiça, assumo a autoridade da minha jurisdição. O pensamento daqueles que não são Ministros deste Tribunal importa como orientação. A eles, porém, não me submeto. Interessa conhecer a doutrina de Barbosa Moreira ou Athos Carneiro. Decido, porém, conforme minha consciência. Precisamos estabelecer nossa autonomia intelectual, para que este Tribunal seja respeitado. É preciso consolidar o entendimento de que os Srs. Ministros Francisco Peçanha Martins e Humberto Gomes de Barros decidem assim, porque pensam assim. E o STJ decide assim, porque a maioria de seus integrantes pensa como esses Ministros. Esse é o pensamento do Superior Tribunal de Justiça, e a doutrina que se amolde a ele. É fundamental expressarmos o que somos. Ninguém nos dá lições. Não somos aprendizes de ninguém. Quando viemos para este Tribunal, corajosamente assumimos a declaração de que temos notável saber jurídico - uma imposição da Constituição Federal. Pode não ser verdade. Em

11 Voto proferido pelo Ministro Humberto Gomes de Barros, nos autos do agravo regimental nos embargos de divergência em recurso especial (AgReg em ERESP) n ${ }^{\circ} 279.889 / A L$. Disponível em: https://ww2.stj.gov.br/revistaeletronica ita.asp? registro $=200101540593 \& \mathrm{dt}$ publicacao $=07 / 04 / 2003$. 
relação a mim, certamente, não é, mas, para efeitos constitucionais, minha investidura obriga-me a pensar que assim seja. Peço vênia ao Sr. Ministro Francisco Peçanha Martins, porque ainda não me convenci dos argumentos de S. Exa. Muito obrigado.

Esta natural possibilidade de entendimentos contraditórios sobre as normas - além de criar incongruências e paradoxos no sistema permite, ainda, que a sua concretização se dê de forma particularizada - não universal - o que leva também à desigualdade.

O princípio do contraditório está internalizado no campo de uma forma irremediável, sendo certo que essa característica se reproduz, inclusive, na formação do saber jurídico. É cediço que o contraditório é uma garantia constitucional, prevista no art. $5^{\circ}$, inciso $\mathrm{LV}$, da $\mathrm{CF} / 88$, sendo categorizado, pela dogmática, como um princípio democrático, um princípio de "justiça", tendo em vista que incorpora a necessidade de que se dê ciência a cada litigante de todos os atos praticados (ou determinados) pelo Juiz e pelo adversário ${ }^{12}$.

Entretanto, a representação empírica do contraditório não é bem esta. De fato, o que se verifica é que, no sistema contraditório, há um estímulo de conteúdo relativamente "bélico", onde a oposição necessária de argumentos prevalece. A tese de uma parte é privilegiada em prol da outra e a suposta "síntese", característica de um processo tipicamente dialético, é, no contraditório, nada mais nada menos, do que a decisão arbitrária da autoridade, não decorrendo, de forma alguma, de um raciocínio logicamente construído, mas do poder que emana do Juiz.

O contraditório é, portanto, caracterizado pelo dever das partes de se contradizerem. Trata-se de um instrumento que possibilita ao Juiz a eleição de teses e que, conseqüentemente, afasta as partes do diálogo, uma vez

12 Oportuno ratificar que o sistema processual brasileiro é contraditório e não adversarial, como, por exemplo, o americano. Quer dizer, as lógicas que o nosso sistema reproduz são necessariamente opostas e excludentes, pois, apenas uma pode prevalecer. Aliás, a título de mera reflexão, o nome que se dá ao princípio é bastante sugestivo. Segundo o Dicionário da Língua Portuguesa de Aurélio Buarque de Holanda, as palavras significam, literalmente: "contraditório: diz-se de duas proposições tais que uma afirma o que a outra nega / adversário: que luta contra.". 
que se sustenta na oposição de pontos de vista, em que, obrigatoriamente, apenas um sairá vencedor, seja ele a parte de um processo, seja um Jurista defendendo uma determinada interpretação legal.

A aplicação desigual da lei é, nesse sentido, legitimada pelo próprio sistema. (KANT DE LIMA, 1995; DAMATTA, 1979).

Daí surgem, inclusive, as situações previstas por DaMatta, quanto à necessidade de cada cidadão se utilizar de suas relações pessoais para se "safar" do manifesto desequilíbrio entre a previsão legal - de cunho teórico - e a viabilidade de cumprimento das leis - de cunho prático. O "sabe com quem está falando" (autoridade) e o "jeitinho brasileiro" (malandragem) são formas situadas entre o "pode" e o "não pode" que os indivíduos ${ }^{13}$ encontraram para conviver com um regramento universalizante e repressor e para enfrentar as contradições e paradoxos dele oriundos, notadamente, no caso do Direito, o fato de o mesmo fato ser julgado de forma absolutamente distinta dependendo do magistrado que irá julgá-lo. (DAMATTA, 1979; 1984).

Este campo acredita em leis perfeitas e universais que, ao regularem as relações sociais, submeterão as pessoas que a elas não se adequarem $^{14}$ à repressão, como se, no Brasil, as leis representassem um contrato social que assegura uma convivência pacífica e consensual entre todos os contratantes.

É assente que em sociedades igualitárias, nas quais, de fato, a democracia se estabeleça - o que não é o caso do Brasil, onde sequer vigora, efetivamente, um Estado Democrático de Direito - as regras são internalizadas pelos sujeitos, tendo em vista que, na verdade, eles são ativos no processo de normalização. Em sociedades desiguais como a

13 DaMatta diferencia a categoria "indivíduo" (sujeito das leis universais) da categoria "pessoa" (sujeito das relações sociais). O "sabe com quem está falando" é a fórmula que magicamente transforma um indivíduo em uma pessoa. DaMatta inclusive ressalta o teor negativo inseparável da palavra indivíduo, sempre ligado a alguém sem princípios. O indivíduo, no Brasil, em vez de ser "alguém”, é "ninguém"; é um qualquer.

14 GEERTZ (1978) explicita a cultura como sendo um ingrediente na formação do homem, que é um ser essencialmente inacabado e incompleto. Nesse sentido, o Direito - como parte da cultura - também funciona como um ingrediente na incessante formação humana, não podendo, portanto, ter a pretensão de regular o comportamento social, reprimindo-o e submetendo-o a padrões prévia e arbitrariamente definidos. 
nossa, tradicionalmente elitistas e hierarquizadas (KANT DE LIMA, 1995), as regras são fruto de imposição e de arbitrariedade; sendo, portanto, exteriores aos sujeitos às quais se aplicam. Leis são - em sociedades desiguais - motivo de ameaça, pois a sua aplicação pressupõe, necessariamente, uma interpretação particularizada, cujos resultados são imprevisíveis. A lei, portanto, não é um instrumento de proteção de todos porque é desigualmente aplicada (AMORIM, KANT DE LIMA, MENDES; 2005).

Daí surge, ainda, um outro fator importante para a compreensão do Direito, qual seja, a tutela do cidadão pelo Estado, representado na pessoa do Juiz. A necessidade de um terceiro - alheio ao processo - ter o poder de decidi-lo no lugar das partes diretamente nele envolvidas, provém da tradição paternalista e tutelar da sociedade brasileira e está arraigado na cultura jurídica de forma irremediável. A idéia de que as pessoas não conseguem, não devem e, portanto, não podem resolver os seus problemas e os seus conflitos, sozinhas - sem a intervenção estatal - é algo que marca a cultura jurídica de uma forma impressionante, de maneira que impedir ou até minimizar a intromissão da tutela jurisdicional na vida particular dos cidadãos é quase um ato de "anarquia".

Em uma sociedade altamente hierárquica, como a brasileira, a existência de uma autoridade decisória - que haja de forma "paternalista" - é fulcral. Ademais, o próprio fato de os indivíduos se reconhecerem como desiguais - como inferiores a quem por eles decide - faz com que a necessidade de um terceiro seja, igualmente, decisiva.

Nesse sentido, essa concepção também reforça a idéia de o Direito se auto-identificar como a solução de todos os males sociais e, conseqüentemente, se colocar em um lugar privilegiado na estrutura social, o que repercute, outrossim, na forma como os próprios operadores do campo se reconhecem e, especialmente, no poder e na autoridade que emanam desse ramo do conhecimento.

Tanto é assim, que os Tribunais, através de seus magistrados, não se definem como administradores dos conflitos sociais que the são encaminhados, mas como "pacificadores de conflitos". O ideal do Direito não é administrar, mas pacificar a sociedade, o que parece absolutamente descabido, tendo em vista que tal pretensão não pertine ao Direito, mas à Sociologia, a partir do momento em que se entende que o conflito é inerente à sociedade, por mais organizada que ela seja.

Além dessas questões, considero relevante salientar, nesse tópico, 
a forma como o Direito se constrói metodologicamente.

Trata-se de uma área onde a metodologia utilizada nas pesquisas é meramente reprodutora, o que advém, me parece, do fato de, nesse ramo do conhecimento, os dados serem considerados como verdades sedimentadas, estabelecidas e incontestáveis, de modo que aos operadores não pode mesmo restar outra alternativa, senão reproduzir o que já está pronto.

Nesse sentido, os trabalhos jurídicos em geral - mesmo os acadêmicos - são recortes que reproduzem tudo o que já fora produzido sobre o mesmo tema e que fora escrito por pessoas consagradas (reconhecidas) no campo, sendo que o número de autores consagrados citados no trabalho é proporcional à qualidade do mesmo ${ }^{15}$ e a suposta originalidade existe quando se busca assuntos equivalentes no "direito comparado", o que significa dizer, quando se busca a doutrina estrangeira.

Ocorre que, o estudo comparado no Direito é absolutamente distinto do estudo comparado nas Ciências Sociais. Sendo o Direito um campo em busca de ideais, "comparar" para o Direito significa ir atrás de um padrão ideal. Busca-se o paradigma internacional e se não existirem no Direito brasileiro as mesmas características daquele, reformula-se o brasileiro, a fim de adequá-lo aos padrões do estrangeiro ${ }^{16}$, o que, na maioria das vezes, não garante êxito, já que se "importam" os institutos sem previamente analisar a sua adequação à realidade ${ }^{17}$.

15 Michel Foucault (2003; p. 76-77), descrevendo como o domínio do saber se firmava na Idade Média, ressalta a disputatio (disputa) como um dos mais célebres rituais de autenticação desse saber. Constituía-se, a disputatio, num ritual de "afrontamento de dois adversários que utilizavam a arma verbal, os processos retóricos e demonstrações baseadas essencialmente no apelo à autoridade"; o que, aliás, nos lembra o atual contraditório. Foucault destaca, abordando o tema, algo que tem íntima relação com o que eu asseverei sobre a falta de criatividade do Direito, dizendo que: “[...] quanto mais autores um dos participantes tivesse a seu lado, quanto mais pudesse invocar testemunhos de autoridade [...] mais possibilidade ele teria de sair vencedor.".

16 Kant de Lima chama a atenção para o fato de que a reação de não encontrar o "mesmo" costuma ser "valorativa-negativa"; ou seja, a ausência ou a não identificação de valores está atrelada à depreciação (Kant de Lima, 1983).

17 Como exemplo, tem-se o due process of law, que é um instituto aplicado ao sistema de administração da justiça criminal americana que foi importado pelo direito brasileiro, sendo traduzido como devido processo legal. A análise empírica do instituto, no Brasil, permite perceber que ele não guarda qualquer relação com 
Fernanda Duarte (2007) destaca e ratifica as questões ora explicitadas de forma bastante objetiva, ressaltando:

[...] De um lado, tem-se a produção doutrinária, marcada pela lógica da repetição que decorre de uma tradição reprodutora de conceitos, categorias e estruturas, descoladas da realidade social brasileira. Em geral, essa doutrina se contenta apenas em dar notícia (ainda que com argumentação bem apresentada e articulada) do debate que se passa no mundo ocidental, pretendendo incorporá-lo de forma automática, no Brasil, como se o seu registro em texto escrito, bastasse para nos "atualizar" e civilizar, colocando nossos autores em sintonia com o que se pensa alhures $[\ldots]$.

$\mathrm{Na}$ Antropologia não é assim. Comparar, para a Antropologia, significa contrastar, isto é, ver o que é essencialmente diferente e, eventualmente, semelhante. Inexiste, nesse sentido, uma preocupação de cunho valorativo. A Antropologia busca a comparação a fim de compreender e de repensar as suas próprias categorias, não a fim de copiar o que encontra no objeto comparado.

O conhecimento jurídico é atualizado de forma a não produzir transformações, mas cópias. Conhecer, nesse campo, equivale a deixar as coisas tal como estão e não intervir na sua forma de atuação. Trata-se de uma visão limitada do conhecimento (KANT DE LIMA; VARELLA, 2001).

Para mim, ao contrário. Explicitar as representações práticas dos institutos jurídicos é a melhor forma de compreendê-los e a Antropologia possibilita isso: analisar, empiricamente, os institutos jurídicos e, com isso, entender as suas distintas categorizações para, então, se for o caso, conhecendo-os, transformá-los.

O que eu sempre li nos manuais de Direito eu jamais tive a oportunidade de vivenciar, até mesmo porque não existe um manual sobre as práticas judiciárias ou sobre as rotinas dos Tribunais, de forma que o due proces of law americano, a não ser a tradução literal do nome. Sobre o tema, ver: FERREIRA, Marco Aurélio Gonçalves. O devido processo legal: um estudo comparado. Rio de Janeiro: Lumen Juris, 2004. 
conciliar isso era a minha porfia.

$\mathrm{Eu}$ nunca tive a pretensão de realizar um trabalho puramente antropológico, porque não sou antropóloga e, mesmo nesse artigo, não tenho a mínima pretensão de parecer uma cientista social. Sou uma advogada, me reconheço no campo do Direito e a minha idéia sempre foi, simplesmente, aliar metodologias que me possibilitassem compreender aquilo que o Direito nunca me explicou.

O fato de utilizar-me da metodologia da Antropologia como ferramenta para realizar trabalho de campo não torna a minha pesquisa não jurídica; ao revés, creio que a Antropologia é fundamental, no sentido de permitir a conciliação de duas formas de manifestação do Direito, a teórica (dogmática) e a empírica (prática).

Busquei contacto com a Antropologia, conforme salientei anteriormente, porque eu não conseguiria dar conta de uma pesquisa que não trouxesse nada novo e que simplesmente reproduzisse a lógica vigente no campo, o que, aliás, como se pode notar, não tem ajudado muito no aprimoramento do Direito.

Eu não conseguiria escrever sobre institutos jurídicos sem conciliálos às rotinas dos Tribunais. A mim, pareceu impossível escrever uma dissertação de mestrado sem escrever sobre algo que eu sei que acontece e que não se vê registrado em livros ou manuais jurídicos.

Para quebrar tradições é necessário explicitá-las; só assim antigos comportamentos são transformados em novos comportamentos. Acredito que a Antropologia ajuda muito nisso. Explicitando as práticas judiciárias podemos transformá-las sempre que elas não estejam mais respondendo aos anseios daqueles que delas se utilizam.

Creio, diante do que vivenciei no decorrer do mestrado, que o Direito não pode mais continuar fechando-se em si porque enquanto não estender suas perspectivas, não encontrará a possibilidade, sequer, de compreender o porquê das dificuldades e das crises que vêm enfrentando.

\section{A pesquisa de campo no Direito: obstáculos e contribuições}

Descrevi outrora que, antes de iniciar propriamente a pesquisa de campo, eu tive de entender em que consistia este tipo de trabalho porque no Direito a empiria é bastante frágil, limitando-se, nosso conhecimento, ao aprendizado das leis, dos procedimentos e dos nomes dos autores que devemos ler quando queremos estudar determinados assuntos. 
Absorvi, em contacto com uma literatura própria das ciências sociais, que, para fazer trabalho de campo, eu deveria, antes de tudo, ir ao Tribunal e ouvir o que as pessoas envolvidas em um processo judicial tinham para dizer a respeito do meu tema, no caso, a manifestação do Princípio da Oralidade no Processo Civil Brasileiro.

Estas pessoas seriam os meus interlocutores (ou informantes), e a minha pesquisa adviria da representação que estas pessoas têm sobre o campo estudado.

Além disso, aprendi que deveria descrever e explicitar o tema de forma absolutamente imparcial, ou seja, eu não poderia jamais induzir os meus entrevistados a responderem aquilo que eu gostaria de ouvir.

Eu deveria estar crua de idéias e pensamentos que pudessem influenciar a minha pesquisa; eu deveria estar aberta aos interlocutores e os meus pontos de vista não poderiam influir na investigação, pois o campo me daria tudo o que fosse preciso para a realização do meu trabalho. Isso foi o mais complicado.

Além de conhecer previamente a doutrina jurídica, eu tinha internalizado algumas representações sobre as práticas judiciárias que eu vivenciava diariamente na minha profissão, portanto, me desligar de tudo isso, iniciar o trabalho e não interpretar os meus dados segundo as minhas convicções foi muito difícil.

A título ilustrativo, narro um fato curioso que me ocorreu. Como se fosse algo natural e imprescindível à pesquisa, eu preparei modelos de questionários padronizados para entrevistar os interlocutores, a respeito da manifestação da oralidade no processo. Elaborei diferentes questionários de acordo com o perfil do entrevistado: fiz um modelo de perguntas para juízes de varas cíveis; outro para juízes de $2^{\mathrm{a}}$ instância; outro para partes; outro para advogados e outro para testemunhas.

Concatenei o questionário de tal forma que a segunda pergunta pressupunha uma resposta específica à primeira e assim sucessivamente. O questionário apontava, com clareza, que eu tinha um padrão para as respostas, como se eu soubesse exatamente o que tinha de ser respondido e, mais, como se eu estivesse disposta a induzir as respostas para o caminho que me interessava.

Se o meu orientador não tivesse me alertado, eu teria, sem me dar conta, funcionado como um típico inquisidor do Tribunal do Santo Ofício, não como uma pesquisadora, e, certamente, os meus dados estariam completamente desvirtuados do contexto real. Nesse sentido, 
desconhecer as metodologias das ciências sociais e estar tão vinculada ao modo de (re) produção em que se fundamenta a pesquisa no Direito foi um complicador para mim.

Chamam a atenção, também, algumas questões que enfrentei diretamente em campo, nas entrevistas com os magistrados.

Por exemplo, em relação à ausência de questionários - dos quais, logicamente, eu desisti após o evento "inquisitorial” acima narrado - os magistrados entrevistados não compreendiam a possibilidade de eu não ter perguntas previamente fabricadas para contextualizar o tema. Além disso, não compreendiam o porquê das minhas perguntas, "tão óbvias e possíveis de se encontrar em qualquer manual de Direito".

Certa vez, um magistrado não resistiu e asseverou:

É um prazer recebê-la, para mim não há problema algum em conceder esta entrevista, mas, sinceramente, para quê você está utilizando o seu tempo agendando entrevistas, vindo até o fórum, gravando tudo, para saber coisas que estão em livros ótimos, de autores reconhecidos, que eu posso até indicar? Aonde você pretende chegar e qual, objetivamente, é o seu intuito com este trabalho?

Tentei explicitar o meu objeto, não apenas para esse Juiz, mas para muitas pessoas da área, entretanto, obviamente, não fui compreendida. A metodologia voltada à pesquisa de campo é desconhecida no Direito.

Percebi claramente que a idéia preponderante do campo era a seguinte: se o meu trabalho não era a reprodução do pensamento de alguém considerado importante pelo Direito, ele não era jurídico. Cheguei a pensar - e, na verdade, até hoje tenho essa impressão - que algumas pessoas do campo jurídico assimilaram o meu trabalho muito mais como uma aventura cênica pelos corredores do fórum do que como uma dissertação defendida em um curso de Mestrado em Direito.

Ocorreu, algumas vezes, durante a minha pesquisa, de alguns magistrados que me conheciam como advogada se sentirem constrangidos em responder a determinadas perguntas que eu fazia. Eles ficavam pouco à vontade em esclarecer questões que lhes pareciam óbvias. Eu perguntava, por exemplo, em que atos processuais a oralidade se materializa e eles 
diziam: "Ah Doutora, como a Senhora já sabe ...”.

Outro dado importante observado na pesquisa de campo - ainda em relação às entrevistas com os juízes - diz respeito à influência que a formação jurídica universitária, já citada neste texto, exerce sobre os seus operadores (BOURDIEU, 1987).

Alguns dos juízes por mim entrevistados estão de tal forma condicionados a se utilizarem de doutrina e de conceitos de autores já consagrados para ratificar os seus pensamentos, que não conseguiam opinar livremente na entrevista, quer dizer, sem fazer menção a algum jurista em quem apoiassem a idéia que sustentavam. É como se a informação que me concediam somente me servisse se fosse avalizada por alguém de renome, a quem eles necessitavam fazer referência expressa, como argumento de autoridade $^{18}$.

Nesses momentos, em que estive com juízes assim, tinha na minha cabeça a idéia de que, para eles, dar entrevistas era como proferir uma sentença, porque eles tinham uma convicção formada, mas precisavam fundamentar esta convicção, comprovando, com o discurso dogmático, que o que diziam tinha fundamento.

Isto ocorreu mais de uma vez, sendo emblemático um fato que vivenciei. Em uma determinada entrevista agendada com uma juíza, aconteceu algo muito curioso. Eu marquei para uma data e quando cheguei, ela me pediu desculpas e disse que não estava preparada, que havia esquecido, solicitando-me que retornasse um outro dia. Agendamos uma nova data e eu saí do gabinete sem compreender exatamente o que significava ela "não estar preparada". Retornei no dia designado e me surpreendi sobremaneira: ela havia estudado com afinco o princípio da oralidade para me conceder a entrevista. Havia lido vários livros de doutrina, sublinhado algumas notas e estava com todo o material preparado na hora em que cheguei. Tudo estava sobre a sua mesa. A entrevista foi mecânica, com citações de autores do início ao fim e, obviamente, embora a magistrada tenha sido inigualável em termos de atenção e cortesia, não colaborou com a pesquisa da forma como eu esperava.

A atitude desses entrevistados me ajudou a perceber três questões

18 O Professor Roberto Kant de Lima chamou-me a atenção em uma aula, certa vez, dizendo-me que o problema do argumento de autoridade, tão firme no Direito, é que ele se baseia na autoridade e não, propriamente, no argumento. E, de fato, no Direito é assim. Mais vale a autoridade do que o conteúdo do que se sustenta (KANT DE LIMA, 2005, p. 92). 
fundamentais para entender a estrutura do campo: 1) a necessidade pessoal dos juristas de saberem sempre todas as respostas, ou seja, a impossibilidade de não conhecerem algum assunto jurídico; o que - no decorrer da pesquisa - verifiquei tratar-se de uma exigência, inclusive, para o exercício do cargo de juiz; 2) o fato de que a opinião no Direito só tem legitimidade se estiver fundamentada na doutrina; 3) a circunstância de os juristas, efetivamente, não saberem como se faz uma pesquisa empírica, porque, diante do comportamento, demonstraram que, a seu ver, eu estaria ali para testar o seu conhecimento, ou para investigá-los, enfim, para saber algo que eles não poderiam, em hipótese alguma, desconhecer.

Este traço assinala um relevante aspecto da cultura jurídica brasileira: a ameaça pelo estigma do desconhecimento, do erro ou da ignorância. Ainda que todos saibam que é impossível para qualquer ser humano conhecer todo o sistema normativo, desconhecê-lo é uma marca que, no curso da pesquisa, percebi estar vinculada a certo status exigido pelo campo e que serve como álibi para aqueles que estão inseridos se distinguirem dos excluídos.

O fato é que, mesmo no fim da pesquisa, eu não consegui fazer as pessoas inseridas no campo do Direito entenderem que o meu objetivo era explicitar os implícitos; que o meu interesse não era definir a oralidade segundo a doutrina jurídica que já existe sobre o tema, mas explicitá-la como uma categoria que possui representações distintas no campo e que eu não poderia, para estudar o instituto, me prender a uma única categoria do tema, qual seja, a dogmática. Era preciso ouvir as pessoas, distinguir as representações do campo e descrever o que as diferenciava para, assim, compreendê-las de forma mais completa e, com isso, repensá-las.

Eu demorei muito para compreender a metodologia das pesquisas realizadas nas ciências sociais e ainda apresento muitas dificuldades, todavia, aprendi algo com a pesquisa: que as categorias do campo, em realidade, não existem. Elas constituem uma construção e, para identificálas, nós temos de olhar "debaixo" delas, ou seja, desnaturalizá-las, pois é "estranhando" que se reconhece.

Pensei as categorias, então, como sendo os conceitos ou os significados das práticas judiciárias, a partir da perspectiva dos interlocutores.

Quanto à necessidade de "explicitação", lembrei-me de que na vida sempre aplicamos um "jargão" que diz: "o melhor caminho para não resolver um problema é fingir que ele não existe" e do quanto isto tem 
relação com o estudo do Direito no Brasil.

Tive a certeza de que, descrevendo as práticas judiciárias, os problemas obscuros do campo jurídico, inevitavelmente, apareceriam. Hoje, terminada a pesquisa, ratifico: enquanto não existirem estudos voltados a essa interlocução com as metodologias das ciências sociais, não enxergaremos as incongruências deste campo e as repercussões sociais de suas rotinas.

Descrevi práticas institucionalizadas no Direito, que todos aqueles que vivenciam o cotidiano dos Tribunais conhecem, que são básicas e corriqueiras para quem lida com as rotinas forenses, mas que, sem a explicitação, se tornam um saber exclusivo de quem as experimenta. Tais práticas só existem dentro dos muros dos Tribunais, pois, dali para fora, ninguém as compreende, tanto porque sobre elas não se escreve, quanto porque, quando se escreve, o que se descreve é completamente diferente do que se realiza.

O Direito faz parte da vida dos cidadãos. Ele influencia o seu cotidiano e, portanto, as pessoas precisam ser socializadas com as suas regras, com a sua estrutura e com o seu funcionamento. Sem isso, o Direito não conseguirá a legitimidade que busca. Nesse sentido, descrever o óbvio é uma forma de tornar conhecidos os mecanismos do Direito.

Por fim, destaco o último - mas não menos tortuoso - obstáculo que tive de enfrentar na tentativa de vivenciar o Direito a partir de um outro (novo) olhar.

Estruturar o texto e começar a escrever foi problemático e isto, mais uma vez, tem a ver com a formação jurídica.

No Direito, quando se pensa em escrever qualquer coisa definese, a priori, um "marco teórico" para o trabalho. Tanto que, a primeira fase de uma pesquisa jurídica é a elaboração do índice. Sem um índice previamente definido não há forma de se começar um trabalho acadêmico no campo do Direito.

Nas ciências sociais, ao revés, inexiste "marco teórico". São os dados da pesquisa empírica que estruturam o desenvolvimento do trabalho. A realidade investigada é que dá vida ao texto a ser escrito ${ }^{19}$.

A razão de tal disparidade é simples: no Direito a realidade deve se adequar à teoria. As leis são padronizadoras do comportamento social 19 DaMatta destaca que nas ciências sociais o pesquisador trabalha com fenômenos que estão "bem perto" dele; eventos humanos, fatos que o pertencem integralmente. (DAMATTA, 1984). 
e, conseqüentemente, tudo o que está entrelaçado nesse campo possui certezas prévias. A essência desse "campo" é "doutrinária" e - como o próprio significado da palavra doutrina (ensinamento) aponta - trata-se, este campo, de um meio em que a pretensão é sempre ensinar por se supor que não há mais nada para se aprender.

Em sendo assim, no Direito, os dados da realidade que não ratifiquem o "marco teórico" previamente definido para o trabalho devem ser dele expurgados: fecha-se os olhos para a sua incontestável existência. Há um desejo muito presente no campo de manter os fatos à distância em procedimentos jurídicos e, nesse contexto, o Direito acaba se afastando, cada vez mais, da estória real e completa (GEERTZ, 1998). Como, aliás, fazem os advogados quando se deparam com uma "tese" que não atende aos seus interesses; simplesmente fingem que ela não existe e buscam outra que lhes tenha serventia.

Nas ciências sociais, a realidade não se sujeita a coisa alguma. A realidade fala; a realidade se apresenta; e cabe ao pesquisador, apenas, explicitá-la.

Quando eu me vi perdida entre esses dois métodos, meu orientador, mais uma vez, acalmou-me. Citando o seu Professor Castro Faria, ele me disse que eu deveria, simplesmente, "ouvir os dados do campo, porque eles têm vida; eles falam”. Entendi e internalizei o significado disso. A dificuldade perdurou porque eu não estava, efetivamente, socializada com essa forma de pesquisar, entretanto, compreender essa idéia foi o pontapé fundamental para que eu pudesse - finalizado o campo - iniciar a sua descrição de forma sistemática e organizada.

Enfim, reputo importante descrever que viver entre o Direito e a Antropologia - dois campos aparentemente antagônicos, mas, de fato, complementares - aguçou a minha sensibilidade para os problemas teóricos que limitam o sistema jurídico a exercer, na prática, a sua função: dar às pessoas a solução "justa" que elas buscam para os seus problemas.

O ensino jurídico é "manualesco" e eu necessitava da vitalidade do mundo das práticas. Sem dúvida, foi essa a mais fundamental contribuição que me foi dada pela Antropologia: a possibilidade de trabalhar, academicamente, questões que estão fervilhando nos Tribunais, porém o próprio campo obscurece.

Fernanda Duarte (2007), mais uma vez, colabora, ajudando a compreender o Direito e sua dificuldade de lidar com essas questões: 
Se olharmos o que os livros falam do Poder Judiciário, de sua essencialidade para a manutenção da democracia e proteção dos direitos fundamentais (Sampaio, 2002), e se olharmos para a própria compreensão que a corporação judicial tem de si não se enxergará nenhuma intencionalidade maquiavélica, explicitada como um complô orquestrado pela toga contra o estado democrático de direito. Trata-se, creio eu, de algo mais profundo, mascarado por um processo reprodutor das práticas que vigoram no campo jurídico e que destoam, em muitas das vezes, da herança moderna do mundo ocidental. Ao comporem o habitus do campo, são compartilhadas por todos seus integrantes, não se refletindo só nos juízes. Entretanto, como o exercício da autoridade estatal é feita pelo juiz, sua participação se torna protagonista, a quem se imputam os "resultados" do sistema jurídico. [...] Assim, é preciso investigar para além do que a doutrina jurídica ensina e para além da compreensão do que a própria magistratura diz ter de sua "missão". È necessário desvendar os mecanismos lógicos que operam essa desigualdade e ao mesmo tempo a tornam invisível.

O que a Antropologia nos fornece, através de sua metodologia, são formas de descobrir o que está encoberto pelo fenômeno da "naturalização". Através do campo, pude perceber que o conhecimento produzido a partir da análise dos dados colhidos na pesquisa é legítimo não por advir do poder ou da autoridade de alguém, mas por representar exatamente aquilo que as pessoas envolvidas no sistema pesquisado pensam a respeito de suas categorias e instituições. Desse modo, a mim pareceu que o campo possibilita a percepção de uma realidade "viva", dinâmica, uma vez que os fatos estão acontecendo enquanto se procede à pesquisa; ao passo que o estudo abstrato do Direito, formalizado pela dogmática, por ser estático e, especialmente, por não ouvir aqueles que estão diretamente envolvidos com o objeto da pesquisa, não corresponde à realidade investigada, daí a sua ilegitimidade. 


\section{Conclusão}

Reputo oportuno manifestar, neste momento final do trabalho, que a minha preocupação nunca foi solucionar os problemas do Judiciário, nem mesmo criticar as suas posturas. A minha proposta foi a de explicitar, do ponto de vista pragmático, como o Direito se materializa no cotidiano dos Tribunais. Acredito que demonstrando, às claras, exatamente como a Justiça se estrutura, se organiza e administra os seus conflitos, estarei possibilitando, ainda que de forma indireta, o aperfeiçoamento do sistema vigente. Abrir os olhos e estranhar o que aparentemente parece natural é sempre uma forma mais fácil de recriação e aprimoramento.

A pesquisa não foi realizada com o intuito de criticar ou elogiar; de acusar ou omitir; de investigar ou silenciar. Na verdade, a minha idéia foi, simplesmente, descrever a realidade do Judiciário, tendo em conta os pontos de vista de todos os envolvidos nessa estrutura: os que julgam e os que são julgados.

Acredito que as considerações manifestadas neste trabalho seriam melhor visualizadas e compreendidas se eu descrevesse alguns dados da pesquisa empírica que efetivamente realizei no âmbito do Judiciário Estadual. No entanto, este espaço objetivava, apenas, apontar linhas gerias sobre a relevância do diálogo entre o Direito e a Antropologia ${ }^{20}$.

Espero ter atingido a finalidade deste trabalho, permitindo a reflexão sobre os temas levantados. A minha proposição foi estudar o Direito sob um novo olhar, de modo a entender as lógicas que regem a sua concretização. A minha busca foi por conhecer como o Direito se materializa e entender o porquê das práticas se apresentarem como se apresentam, independentemente do que proclamam os manuais.

A imensa carga de trabalho que assola o Judiciário automatiza os operadores do campo, impedindo-os de pensar sobre suas próprias atividades e, no caso específico dos magistrados, sobre o resultado da jurisdição que prestam.

A pesquisa de campo procede, justamente, à observação de fatos e fenômenos tal como ocorrem no mundo real, bem como à coleta de dados referentes aos mesmos e, finalmente, à análise e interpretação desses dados, 20 Para que se tenha mais clareza sobre os resultados obtidos a partir do diálogo entre o Direito e a Antropologia, remeto-lhes à leitura da minha dissertação de Mestrado: "O Princípio da Oralidade às avessas: um estudo empírico sobre a construção da verdade no processo civil brasileiro". 
com base numa fundamentação teórica consistente, objetivando compreender e explicar o problema pesquisado.

Nesse âmbito, explicitar os rituais judiciários tem de ser o foco prioritário da pesquisa - mesmo que tal metodologia seja incomum no campo jurídico - porque somente descrevendo e desnaturalizando (ou desconstruindo) as supostas "certezas" do Direito, será possível repensar a estrutura processual vigente e entender os seus mecanismos, de forma a, talvez, possibilitar que se dê início ao seu aprimoramento. Sem entender isso, não haverá como sequer tentar efetivar transformações eficazes.

Percebo que, normalmente, os trabalhos jurídicos - inclusive os acadêmicos - priorizam explanar os motivos pelos quais a idealização dogmática do Direito não se materializa. Esta, efetivamente, não foi a minha idéia. Na pesquisa realizada, eu pretendi desnudar (ou enxergar além) determinadas categorias fixas e imutáveis do Direito, utilizandome, através do método etnográfico, de mecanismos de neutralidade e distanciamento que propiciaram uma pesquisa atrelada à realidade.

A Antropologia permitiu que eu ultrapassasse as fechadas visões do campo do Direito e vislumbrasse o mundo empírico dos Tribunais.

Kant de Lima (1983) aborda a necessidade de se "rasgar os véus" do Judiciário e tornar explícitas as suas práticas para que governem essas atividades, regras que sejam definidas e acessíveis a todos; o que hoje ainda não ocorre.

Faço questão de terminar este trabalho reportando-me ao texto que, na verdade, representa o marco da minha interlocução com a Antropologia. Precisamente, foi após ler e entender o significado do trecho a seguir transcrito, extraído do artigo de Kant de Lima, "Por uma Antropologia do Direito no Brasil", que eu entendi e me motivei a pesquisar e desenvolver uma forma de investigação que me possibilitasse traçar um vínculo entre essas duas áreas, o Direito e a Antropologia:

É preciso ouvir os silêncios desse saber-poder, o que nele está implícito naqueles procedimentos sempre tão ritualizados, abertos e formais, de quem nada teme porque nada deve, expressão máxima de seu arbítrio definitivamente impune e irresponsável [...] $\mathrm{Na}$ área do Direito, como apontei, o percurso é tanto mais árduo porque implica na transformação das próprias bases onde se ancora um saber-poder que se difunde 
muito além do jurídico na nossa socialização. Não há glória ou fama nessa luta, nem objetivo a ser alcançado, porfia-se porquanto é bom porfiar [...]. (grifou-se)

\section{Bibliografia}

AMORIM, Maria Stella de; KANT DE LIMA, Roberto; MENDES, Regina Lúcia Teixeira (Org.) Ensaios sobre a igualdade jurídica: acesso à justiça criminal e direitos de cidadania no Brasil. Rio de Janeiro: Lumen Juris, 2005, introdução.

BERMAN, Harold J. La formación de la tradición jurídica de occidente. México: Fondo de Cultura Econômica, 1996.

BOURDIEU, Pierre. Campo Intelectual e Projeto Criador. In:

Problemas do Estruturalismo. Rio de Janeiro: Zahar Editores, 1968, p. 105143.

BOURDEU, Pierre; CHAMBOREDON, Jean-Claude; PASSERON, JeanClaude. Ofício de Sociólogo: metodologia da pesquisa na sociologia. Tradução de Guilherme João de Freitas Teixeira. Petrópolis: Vozes, 2004, introdução.

DAMATTA, Roberto. Você sabe com quem está falando? In:

Carnavais, Malandros e Heróis: para uma sociologia do dilema brasileiro. Rio de Janeiro: Zahar, 1979, p. 139-193.

95-105.

. O que faz o brasil, Brasil? Rio de Janeiro: Rocco, 1984. p.

DUARTE, Fernanda. A construção da verdade no processo civil e a igualdade jurídica. Revista do Curso de Gestão em Segurança Pública e Justiça Criminal da Universidade Federal Fluminense (no prelo)

FOUCAULT, Michel. A verdade e as formas jurídicas. Rio de Janeiro: Nau, 2003. 
GARAPON, Antoine. Bem Julgar: ensaio sobre o ritual judiciário. Lisboa: Instituto Piaget, 1997.

GEERTZ, Clifford. O Impacto do Conceito de Cultura sobre o Conceito de Homem. In: Zahar, 1978, p. 45-66. . A interpretação das culturas. Rio de Janeiro: Jorge

. O saber local: fatos e leis em uma perspectiva comparativa. In: . O Saber Local. Petrópolis, Vozes, 1998, p. 249-356.

KANT DE LIMA, Roberto. Por uma Antropologia do Direito no Brasil. In: FALCÃO, Joaquim de Arruda. Pesquisa Científica e Direito. Recife: Massangana, 1983. p. 89-116.

. A Antropologia da Academia: quando os índios somos nós. Niterói: EdUFF, 1997.

A Polícia da Cidade do Rio de Janeiro: seus dilemas e paradoxos. Rio de Janeiro: Forense, 1995.

; VARELLA, Alex. Saber Jurídico e Direito à Diferença no Brasil: questões de teoria e método em uma perspectiva comparada. Rio de Janeiro: Revista Ciências Sociais, UGF, vol. 7, n. 1, 2001, p. 38-65.

MENDES, Regina Lúcia Teixeira. O Princípio da Isonomia à Brasileira: igualdade é tratar desigualmente os desiguais. 2003. Dissertação (Mestrado em Direito) - Programa de Pós-graduação em Direito da Universidade Gama Filho, Rio de Janeiro.

MOREIRA-LEITE, Ângela. Em tempo de conciliação. Niterói: EdUFF, 2003. 